\title{
Simulasi Pola Sebaran Logam Berat Tembaga (Cu) di Perairan Kota Pekalongan
}

\author{
Osen Faber Romario Tampubolon ${ }^{1 *}$, Aris Ismanto', Agus Anugroho Dwi Suryo ${ }^{1}$, Muslim ${ }^{1}$, \\ Elis Indrayanti ${ }^{1}$
}

\author{
${ }^{I}$ Departemen Oseanografi, Fakultas Perikanan dan Ilmu Kelautan, Universitas Diponegoro. \\ Jl. Prof. H. Sudarto, SH, Tembalang Semarang, 50275 Telp/fax (024) 7474698 \\ Email :*osentampu@gmail.com
}

\begin{abstract}
Abstrak
Logam tembaga $(\mathrm{Cu})$ banyak digunakan dalam proses produksi suatu industri baik sebagai bahan baku, katalisator ataupun bahan utama. Logam $\mathrm{Cu}$ termasuk ke dalam kelompok logam essensial, karena pada konsentrasi yang rendah dibutuhkan oleh organisme. Namun demikian, pada konsentrasi tinggi logam $\mathrm{Cu}$ ini akan mempunyai sifat toksik. Keberadaan logam dari industri akan mencemari lingkungan perairan, termasuk perairan laut. Kota Pekalongan merupakan salah satu sentra industri tekstil (Batik). Selama proses pembuatan batik ini dapat menghasilkan limbah, logam $\mathrm{Cu}$. Logam $\mathrm{Cu}$ dari daerah indutri akan terbawa oleh aliran air sungai atau run off daratan dan menuju ke perairan laut. Selama berada di perairan laut, logam ini akan mengalami distribusi dan pengenceran oleh arus laut. Tujuan penelitian ini adalah untuk memprediksi sebaran $\mathrm{Cu}$ di Perairan Kota Pekalongan serta simulasi distribusinya dengan pendekatan model matematika dua dimensi. Tahap pemodelan distribusi $\mathrm{Cu}$ menggunakan pemodelan hidrodinamika untuk memprediksi arah dan kecepatan arus laut serta dilanjutkan modul transport untuk memodelkan distribusi $\mathrm{Cu}$. Hasil penelitian menunjukan konsentrasi $\mathrm{Cu}$ di perairan Kota Pekalongan berkisar antara 0,011 - 0,007 mg/l. Simulasi persebaran $\mathrm{Cu}$ di Perairan Kota Pekalongan pada musim timur menunjukan bahwa pola persebaran menuju ke arah Barat.
\end{abstract}

Kata Kunci : Distribusi $\mathrm{Cu}$, hidrodinamika, pemodelan matematika, Perairan Pekalongan.

\begin{abstract}
$\mathrm{Cu}$ (Cuprum) is one of heavy metals than commonly used for industry as raw material, or catalyst. Cu is included in the essential heavy metal group, which is a low level that is needed by organisms, but it's toxic when at a high level. Thus, high concentration of $\mathrm{Cu}$ elements in the waters tends to pollute the waters. Pekalongan City is the center of the textile (Batik) industry, where one of the wastes produced in the batik-making process is heavy metal Cu, which is used during the batik washing process. The purpose of this research is to predict the condition of Cu in the water of Pekalongan City Waters and to simulate its distribution using 2 dimension mathematical model approach. The Cu distribution modeling stage used the hydrodynamic model to predict the direction and velocity of ocean currents, followed by the transport module to model the $\mathrm{Cu}$ distribution. The results show that the $\mathrm{Cu}$ concentration in the waters of Pekalongan City range from $0.011-0.007 \mathrm{mg} / \mathrm{l}$. Simulation of the distribution of $\mathrm{Cu}$ in the waters of Pekalongan City in the eastern season shows that the Cu concentration is distributed westward.
\end{abstract}

Keywords : Cu Distribution, Hydrodynamic Model, Pekalongan City Waters.

\section{PENDAHULUAN}

Perairan Pekalongan memiliki garis pantai kurang lebih sepanjang $6 \mathrm{~km}$ membentang dari Barat ke Timur dan berhadapan langsung dengan Laut Jawa. Secara morfologis pantainya berbentuk landai yang didominasi oleh hamparan pasir, tidak berbatu, perairannya bersifat terbuka, bukan merupakan teluk dan ombak pantainya relatif berkekuatan rendah. Warna perairan pantai keruh kecoklatan dan baru kurang lebih 1 mil warna terlihat hijau kebiruan. Kedalaman perairan pantai antara $0,5-25 \mathrm{~m}$ dengan kecepatan arus yang 
cukup deras (Pemprov Jateng, 2020). Pekalongan sebagai salah satu kota di Jawa Tengah, dikenal sebagai sentra produksi batik di Indonesia. Industri batik merupakan industri utama yang berperan terhadap sektor ekonomi Kota Pekalongan selain sektor perikanan dan kelautan (Mratihatani, 2013).

Fajri (2013) menyatakan bahwa pencemaran sungai di Kota Pekalongan sebagian besar berasal dari pembuangan limbah air dari hasil pada proses pewarnaan batik dan sablon. Limbah industri batik ini mengandung bahan-bahan sintetik yang tidak larut dan sulit diuraikan. Proses pewarnaan menghasilkan limbah cair yang berwarna keruh pekat dan mengandung logam berat. Hasil proses industri batik telah berdampak pada parameter kualitas air seperti COD (Chemical Oxygen Demand), kandungan tembaga, kandungan fosfor, kandungan nitrogen dan lain-lain menjadi di atas ambang baku mutu menurut Keputusan Menteri Negara Lingkungan Hidup Nomor: 115 Tahun 2003 tentang pedoman penentuan status mutu air (Pemerintah Kota Pekalongan, 2020).

Penelitian yang telah dilakukan sebelumnya di perairan Kota Pekalongan akibat dari limbah batik berkaitan dengan studi kualitas perairan Sungai Banger dan berkaitan tentang proses laju sedimentasi di perairan pesisir muara sungai. Penelitian terkait konsentrasi logam berat di perairan Pekalongan juga telah dilakukan pada sampel sedimen. Penelitian tentang bagaimana pola sebaran logam, khususnya $\mathrm{Cu}$ di wilayah muara akibat adanya arus laut belum pernah dilakukan. Muara Sungai Banger dipilih sebagai daerah penelitian karena dianggap sebagai salah satu sungai yang dipengaruhi oleh keberadaan industri batik di Kota Pekalongan. Diharapkan hasil simulasi model persebaran logam berat dalam penelitian ini dapat digunakan sebagai kajian mitigasi bencana terjadinya pencemaran logam $\mathrm{Cu}$, sehingga arah dan pola sebarannya serta luasan dari dampak pencemaran dapat diketahui. Sebaran logam berat tembaga $(\mathrm{Cu})$ dan konsentrasinya di perairan berperan penting dalam penentuan tingkat pencemaran perairan dan pengaruhnya terhadap biota yang ada di perairan itu sendiri.

\section{MATERI DAN METODE}

Materi penelitian yang digunakan dalam penelitian ini meliputi data primer dan data sekunder. Data primer yang digunakan adalah sampel air yang selanjutnya dilakukan pengukuran konsentrasi $\mathrm{Cu}$. Data sekunder berupa peramalan pasang surut perairan Pekalongan, peta bathimetri, debit air sungai Banger, arus laut dan Peta Rupa Bumi Indonesia.

Metode penelitian yang digunakan adalah deskriptif, yaitu metode ilmiah yang meneliti sekelompok objek atau suatu objek, kondisi, sistem atau peristiwa pada masa sekarang (Sudjana, 1992) yang bertujuan untuk menggambarkan suatu keadaan keadaan tertentu. Dalam penelitian akan menggambarkan kondisi logam berat tembaga $(\mathrm{Cu})$ di muara sungai Banger perairan Pekalongan berdasarkan kondisi perairan yang dipengaruhi oleh arus,pasang surut, dan debit sungai Banger, di perairan Pekalongan. Penentuan lokasi penelitian menggunakan metode purposive sampling, yaitu teknik pengambilan sampel dengan pertimbangan tertentu oleh peneliti (Sugiyono, 2009). Lokasi penelitian secara lengkap disajikan pada Gambar 1. 


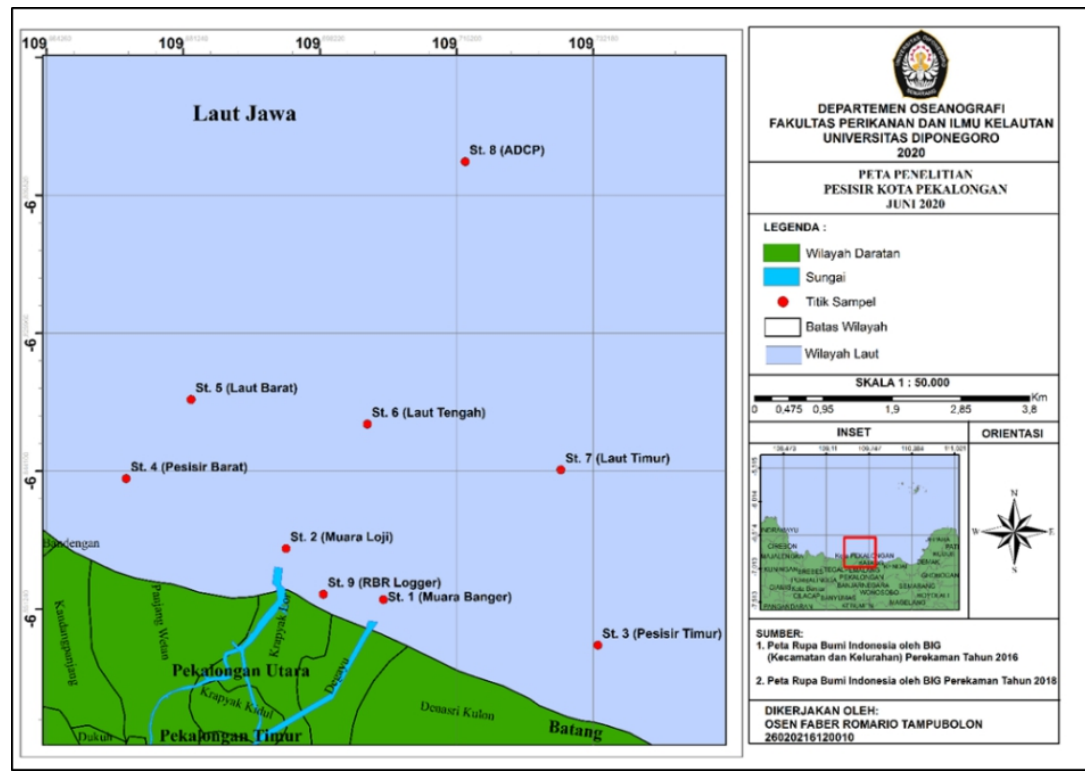

Gambar 1. Peta Lokasi Penelitian dan Titik Pengamatan

Pengambilan sampel air laut dilakukan pada saat kondisi perairan dalam keadaan pasang menuju surut. Sampel air diambil dengan menggunakan botol nansen dengan 2 kali pengulangan $(5-15 \mathrm{~cm}$ dari permukaan) dan selanjutnya dimasukkan ke botol sampel dan disimpan dalam cool box. Semua wadah sampel air dan botol nansen yang digunakan dlakukan pencucian terlebih dahulu sebelum digunakan. Hal ini untuk meminimalisir kontaminasi zat pencemar lainnya (Fitriyah et al., 2011).

Sampel air diambil dengan menggunakan botol nansen minimal sebanyak 2 kali pengulangan. Air sampel diambil pada kolom air tepat sedikit masuk dibawah permukaan air $(5-15 \mathrm{~cm})$, kemudian dimasukkan ke botol sampel yang tidak tembus cahaya dengan volume 2 Liter kemudian disimpan dalam kotak pendingin yang sudah ditambahkan es kristal (cool box).

\section{Analisis Logam Cu}

Analisis konsentrasi logam berat $\mathrm{Cu}$ dilakukan di Balai Pengujian dan Laboratorium Lingkungan Hidup Dinas Lingkungan Hidup dan Kehutanan Provinsi Jawa Tengah dengan menggunakan metode pengujian tembaga $(\mathrm{Cu})$ Spektrofotometri Serapan Atom Graphite Furnace SSA (GF) dengan acuan metode SNI 6989-84:2019.

\section{Pengukuran Pasang Surut}

Data pasang surut perairan Pekalongan diukur langsung menggunakan logger pasut RBR dilapangan dengan mengikatkan alat logger pasut pada sebuah tongkat kayu yang tertancap pada dasar perairan serta ditambahkan dengan hasil peramalam instansi BIG sebagai pembanding data.

\section{Batimetri}

Data batimetri diukur langsung menggunakan echosounder dimana GPS dan Tranduser diletakkan pada posisi sejajar vertikal menggunakan tongkat serta dengan kedalaman tranduser yang tercelup sebesar $40 \mathrm{~cm}$. Bathimetri juga diperoleh dari hasil pengolahan data dari instansi terkait yang berwenang untuk mengeluarkan peta bathimetri (PUSHIDROSAL) dan kedua data tersebut diolah untuk memperoleh nilai bathimetri yang lebih presisi. 


\section{Debit Sungai}

Nilai debit air sungai diamati secara langsung (in situ) dengan memperhitungkan dimensi dan kecepatan aliran sungai serta didukung oleh studi literatur atau informasi dari instansi Balai Besar Wilayah sungai (BBWS) Direktorat Jendral Sumber Daya Air, Kementrian PUPR, dan data yang diterbitkan oleh Pemerintah propinsi Jawa Tengah 2019

\section{Data Angin}

Data angin perairan Pekalongan Web Resmi Pemprov Jateng, 2019). dapat diperoleh dari instansi BMKG, Website Pemprov Jateng, dan mendownload langsung pada Website ECMWF.

\section{Arus}

Data arus diukur langsung menggunakan ADCP pada titik yang ditentukan dengan interval priode waktu pengukuran setiap 10 menit sepanjang 3 hari pengamatan, yang nanti akan digunakan untuk memverifikasi arus hasil pemodelan.

\section{Tahap Validasi}

Menurut Prasetya et al. (2017) pemodelan yang akurat membutuhkan representasi yang memadai baik mengenai parameter, proses dan kondisi batasan model. Aspek-aspek penting yang di perlukan sebagai pertimbangan dalam memilih/membuat sebuah model:

1) Kesesuain dengan kondisi sesungguhnya, harus berhubungan dengan asumsi-asumsi yang diambil sebelum membuat model.

2) Kepentingan pemodel sesuai dengan informasi yang dibutuhkan.

3) Perlu validasi data berdasarkan pengalaman yang telah ada.

Untuk memastikan bahwa model yang akan digunakan sebagai analisis maka sebelumnya perlu dilakukan verifikasi terhadap hasil yang diperoleh dari simulasi dengan hasil pengamatan di lapangan; grafik pasang surut untuk membandingkan hasil model dan pengamatan serta verivikasi arus.

Verifikasi model dilakukan dengan menghitung Root Mean Square (RMS Error). RMSE merupakan pengukuran yang menyatakan perbandingan antara nilai pengamatan dengan nilai hasil pemodelan (Chai and Draxler, 2014). Nilai RMSE dinyatakan dengan persamaan berikut :

$$
R M S E=\sqrt{\frac{\sum_{i=1}^{n}\left(x_{o b x, i}-x_{\text {model }, i}\right)^{2}}{n}}
$$

Dimana Xobs, $i$ menyatakan nilai observasi dan Xmodel, $i$ adalah nilai model; sedangkan $n$ adalah banyaknya populasi. Proses verifikasi ini, dilihat sejauh mana kemiripan hasil simulasi terhadap data lapangan dan eror data.

\section{HASIL DAN PEMBAHASAN}

\section{Kondisi Pasang Surut}

Kondisi pasang surut daerah penelitian disajikan pada Gambar 2. Data elevasi muka air laut hasil pemodelan memiliki kemiripan dengan data elevasi muka air laut hasil observasi lapangan yaitu menunjukkan pola pasang surut yang sama yaitu campuran condong harian tunggal (mixed tide prevailing diurnal). Hasil tersebut juga didukung oleh hasil validasi secara kuantitatif dengan nilai koefisien determinasi $\left(\mathrm{R}^{2}\right)$ cukup baik sebesar 0,6. Nilai ini menggambarkan bahwa nilai pasang surut hasil pemodelan dan hasil pengukuran lapangan memiliki hubungan korelasi yang baik dengan mendekati nilai 1. Ismanto et al., (2019), menjelaskan bahwa besar magnitudo dan fase dari elevasi muka air model sudah mampu merepresentasikan kondisi di alam dan model memiliki kriteria yang cukup bagus, jika memiliki koefisien determinasi 
mendekati 1. Selanjutnya setelah dilakukan dengan uji RMSE, model juga memiliki nilai eror yang cukup kecil mendekati 0 yaitu 0,16 . Elevasi muka air laut hasil model memiliki nilai eror yang kecil mendekati 0 dan nilai koefisien determinasi mendekati 1, maka model tersebut dikatakan sudah mampu untuk menggambarkan elevasi muka air laut di alam (Ismanto et al., 2019). Dengan demikian hasil model pasut sudah dapat digunakan sebagai tahap awal pemodelan untuk sebaran logam $\mathrm{Cu}$ di perairan Kota Pekalongan.

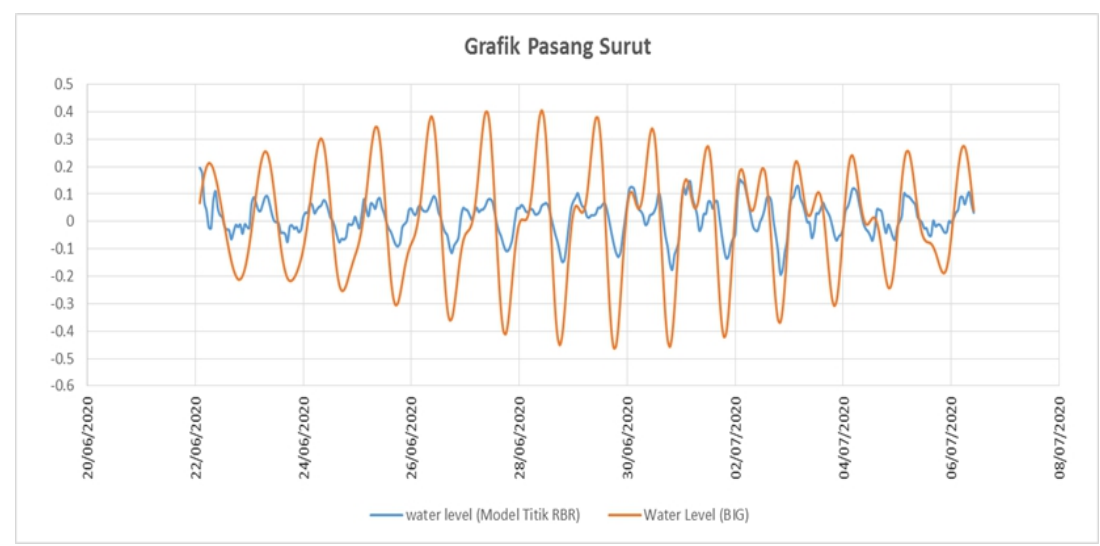

Gambar 2. Grafik Pasang Surut BIG dan Pemodelan Pada Titik RBR Logger Pasut.

Arus

Data Arus hasil pemodelan diolah dengan pemodelan matematika dua dimensi. Simulasi pemodelan dilakukan selama 15 hari (22 Juni-06 Juli 2020). Kondisi pola arus hasil simulasi model saat pengambilan sampel di sajikan pada Gambar 3. Selanjutnya vektor arus tersebut diuraikan komponennya kecepatannya berdasarkan komponen u (kecepatan arah $\mathrm{x}$ ) dan v (kecepatan arah y) (Gambar 4 dan Gambar 5).
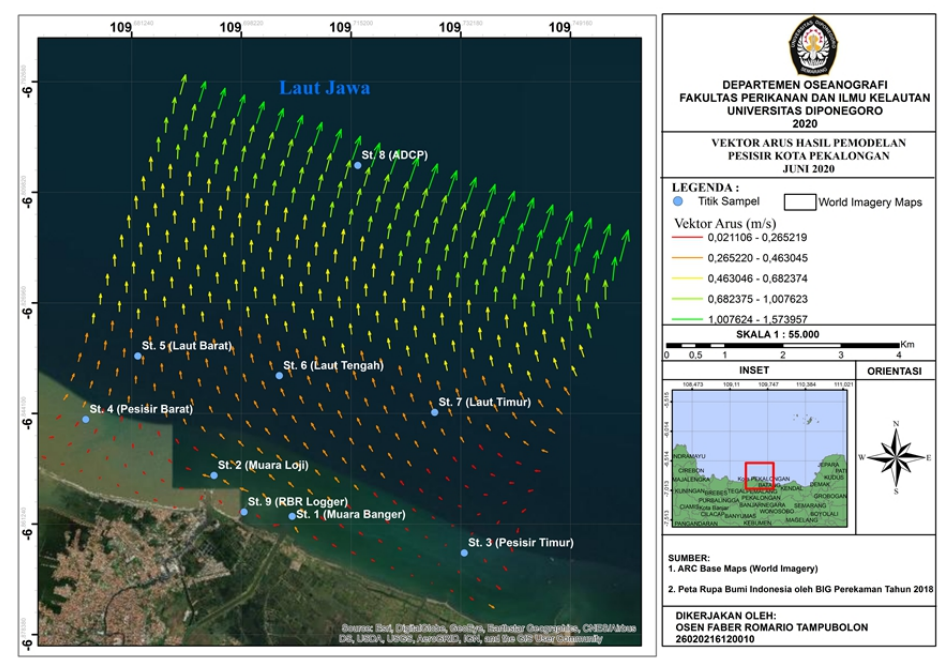

Gambar 3. Pola Pergerakan Arus Pada Saat Pengambilan Sampel air (24 Juni 2020, pada kondisi pasang menuju surut) 


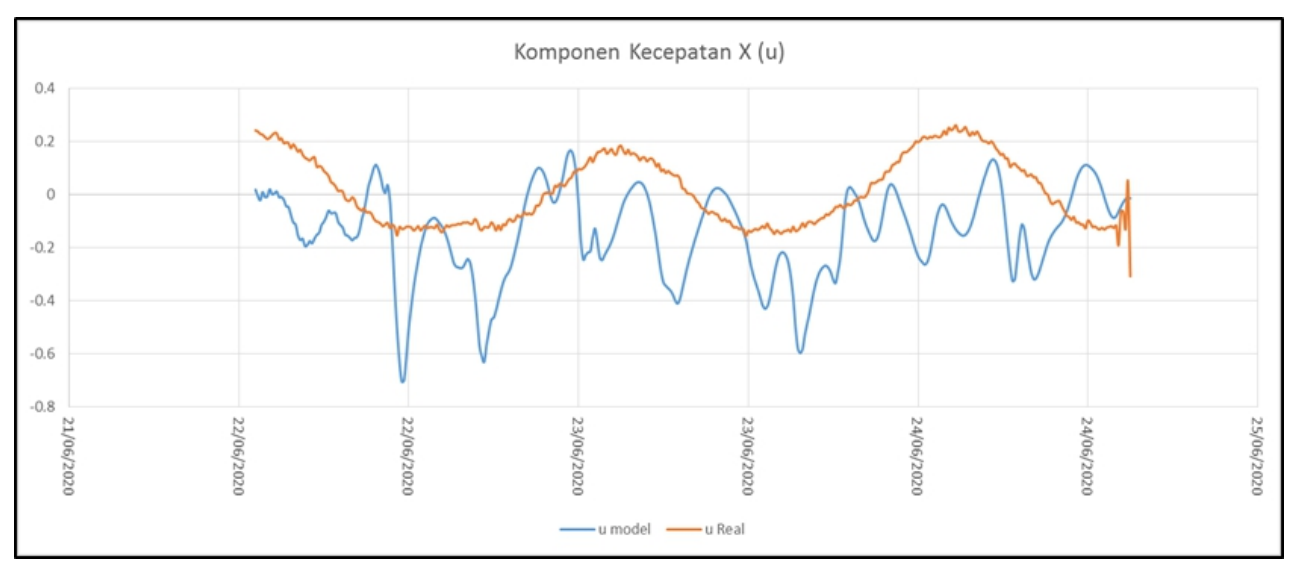

Gambar 4. Grafik Komponen Kecepatan Arah X (u).

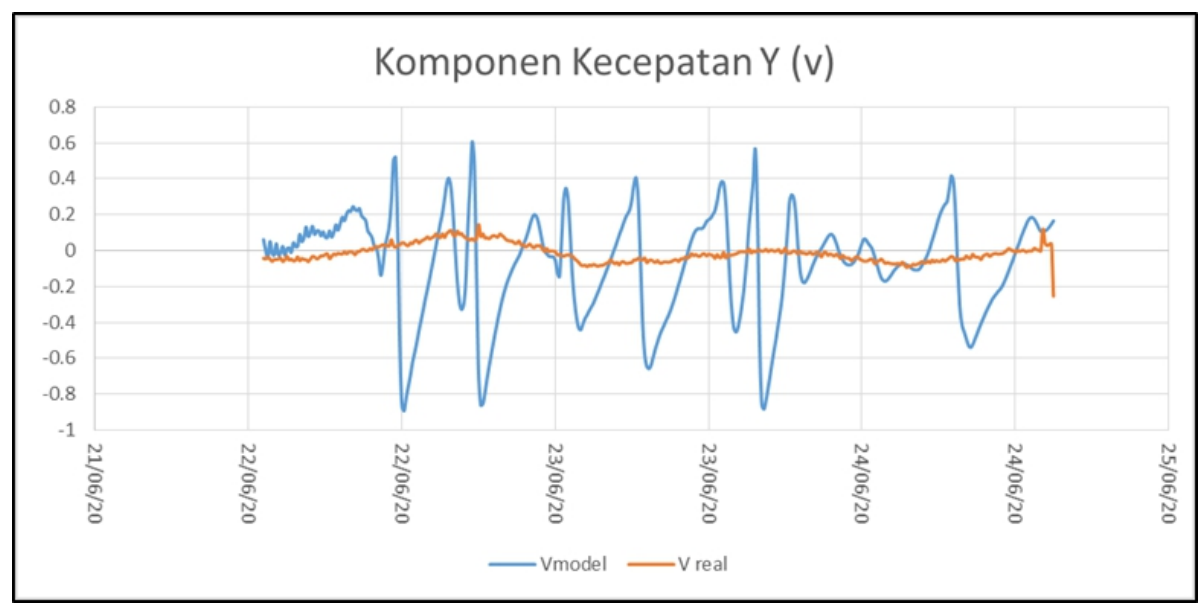

Gambar 5. Grafik Komponen Kecepatan Arah Y (v).

Selanjutnya data kecepatan arah $\mathrm{u}$ dan $\mathrm{v}$ hasil model dilakukan verifikasi dengan data kecepatan arah arus dari hasil pengukuran lapangan. Verifikasi dilakukan dengan melihat nilai korelasi kedua variabel tersebut. Hubungan korelasi kedua parameter selengkapnya disajikan pada Gambar 6 dan Gambar 7.

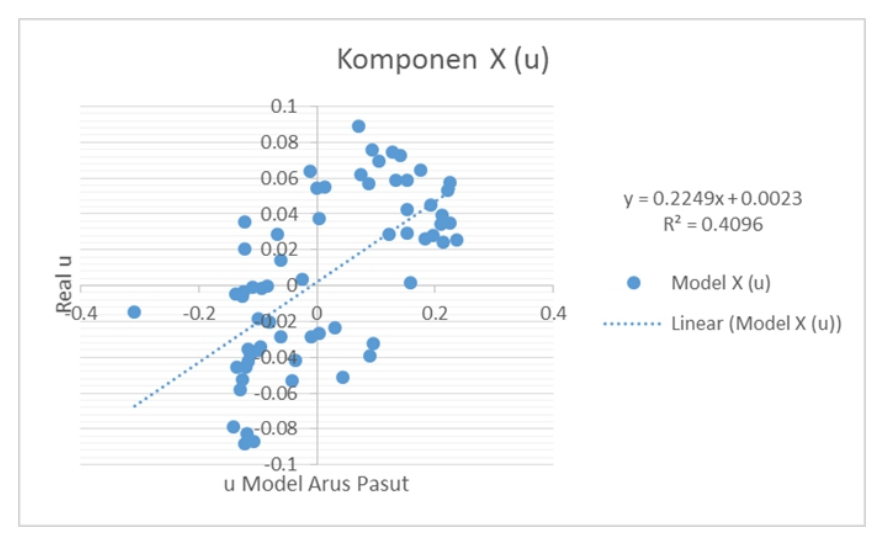

Gambar 6. Korelasi Kecepatan Arah U Hasil Pemodelan dan ADCP Lapangan. 


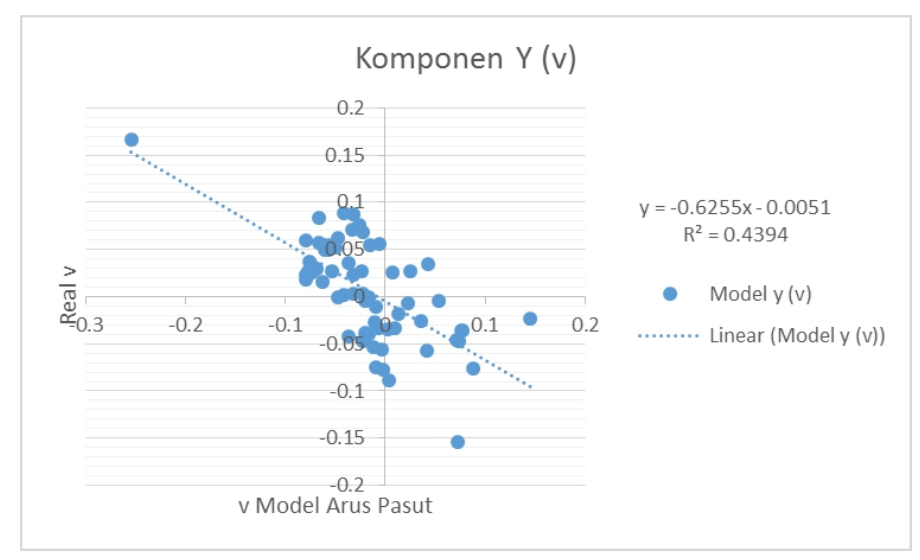

Gambar 7. Korelasi Kecepatan Arah V Hasil Pemodelan dan ADCP Lapangan.

Pada hasil pemodelan komponen kecepatan $\mathrm{u}$ dan $\mathrm{v}$ didapatkan kecepatan arus maksimum adalah berturut-turut sebesar $0,17 \mathrm{~m} / \mathrm{s}$ dan $0,59 \mathrm{~m} / \mathrm{s}$. Hasil tersebut tidak jauh berbeda dari hasil data yang diperoleh dilapangan untuk komponen kecepatan $u$ dan $v$ yaitu sebesar $0,22 \mathrm{~m} / \mathrm{s}$ dan $0,18 \mathrm{~m} / \mathrm{s}$. Pola kecepatan arus hasil pemodelan dan data lapangan dapat dilihat pada gambar diatas. Berdasarkan gambar tersebut dapat dilihat bahwa pola arus hasil pemodelan dan hasil observasi lapangan memiliki kemiripan. Arus hasil pemodelan dan lapangan memilki hubungan korelasi yang cukup baik dengan nilai korelasi /R-squared (R2) komponen $\mathrm{u}$ dan $\mathrm{v}$ berturut-turut 0,41 dan 0,44. Selain membandingkan kecepatan arus komponen $\mathrm{u}$ dan $\mathrm{v}$, dilakukan juga pembuatan grafik residu dari kecepatan arus hasil pemodelan dan hasil observasi lapangan yang menunjukkan nilai kecepatan arus maksimum $0,086 \mathrm{~m} / \mathrm{s}$.

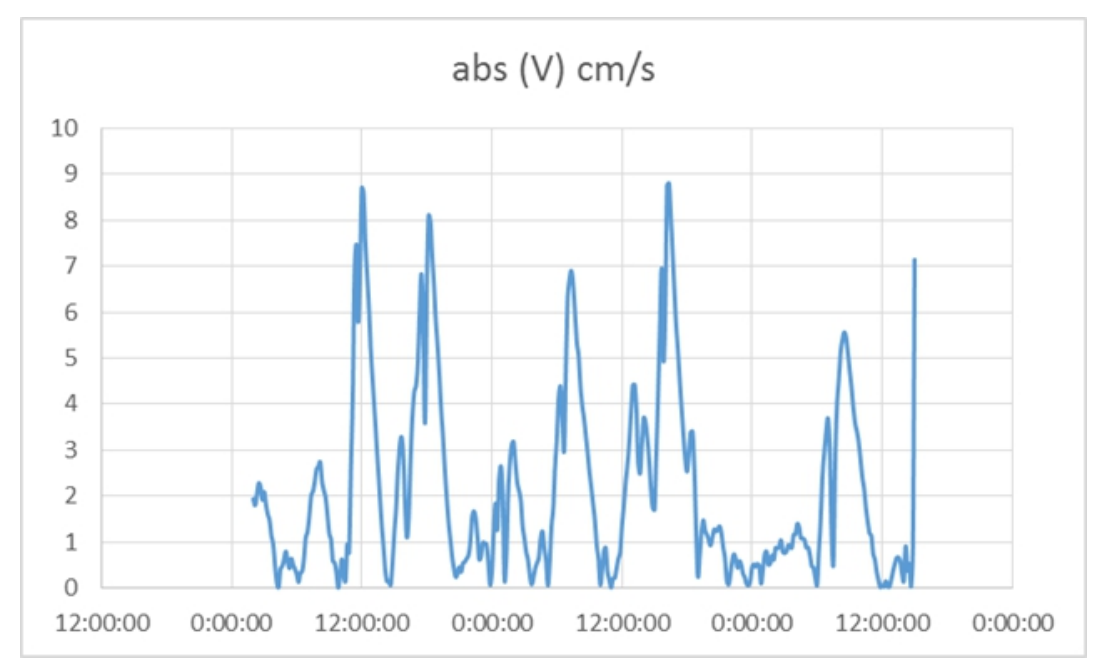

Gambar 8. Absolute Residu Kecepatan Pemodelan dan ADCP Lapangan 


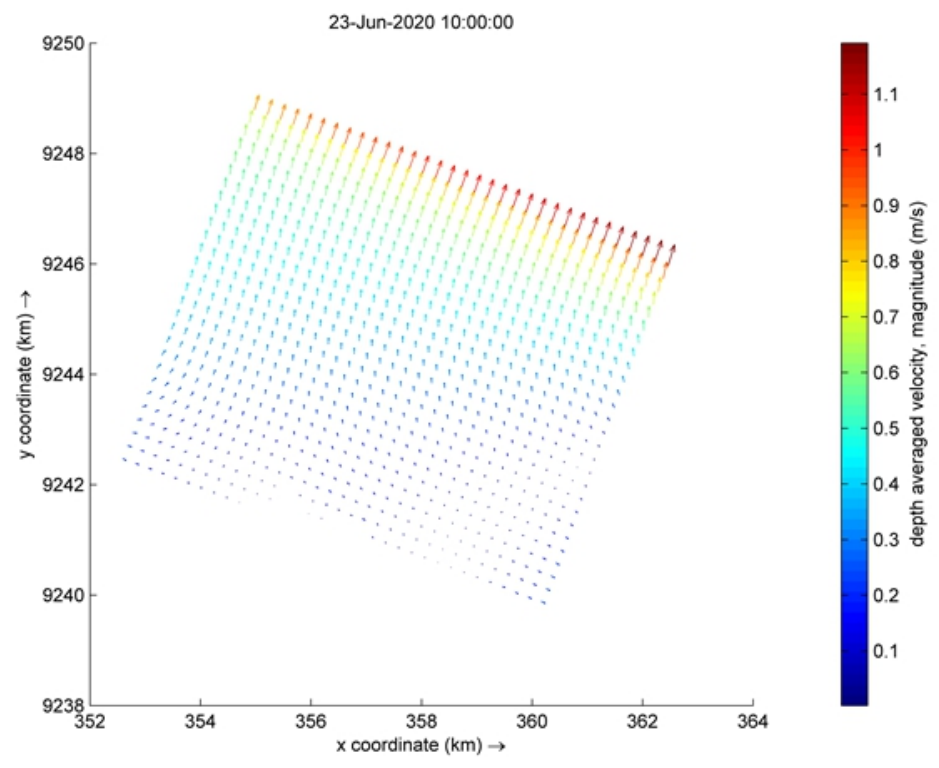

Gambar 9. Pola Pergerakan Arus 23 juni 2020 - Kondisi Pasang Menuju Surut

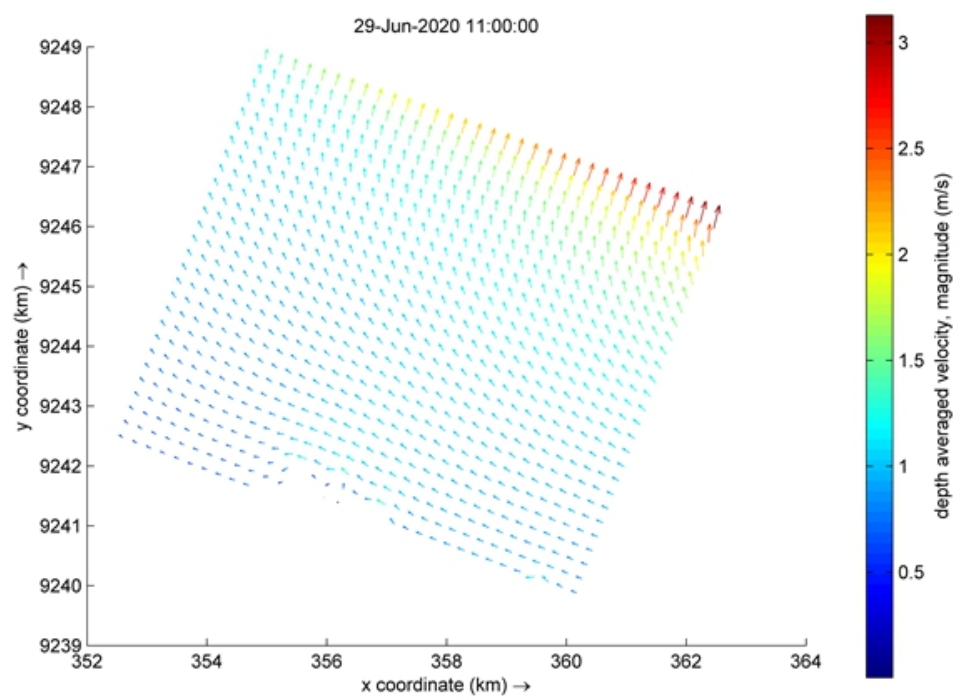

Gambar 10. Pola Pergerakan Arus 29 juni 2020 - Kondisi Pasang Menuju Surut 


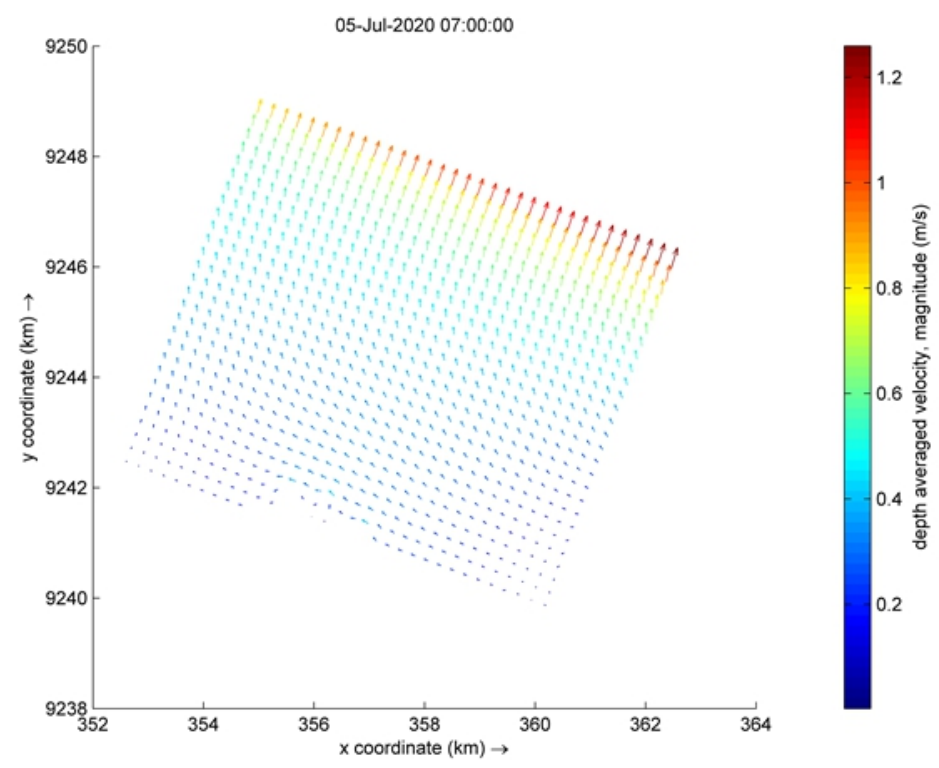

Gambar 11. Pola Pergerakan Arus 05 Juli 2020 - Kondisi Pasang Menuju Surut

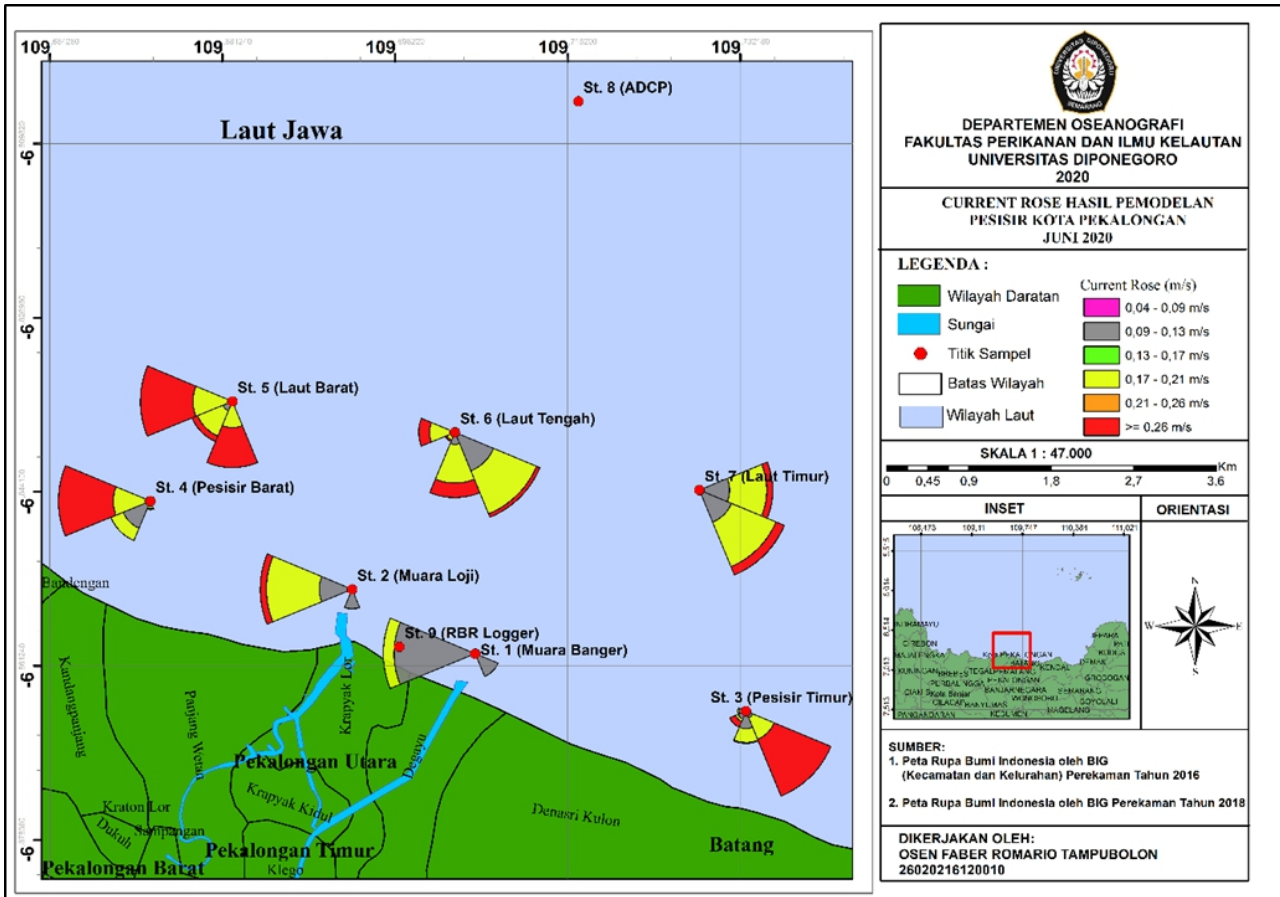

Gambar 12. Current Rose di Setiap Stasiun Pengamatan 


\section{Persebaran Cu (Cuprum)}

Persebaran $\mathrm{Cu}$ (Cuprum) hasil pemodelan diolah dengan pendekatan model matematika dua dimensi (Deltares, 2014), panjang waktu pemodelan 15 hari (22 juni-06 Juli 2020).

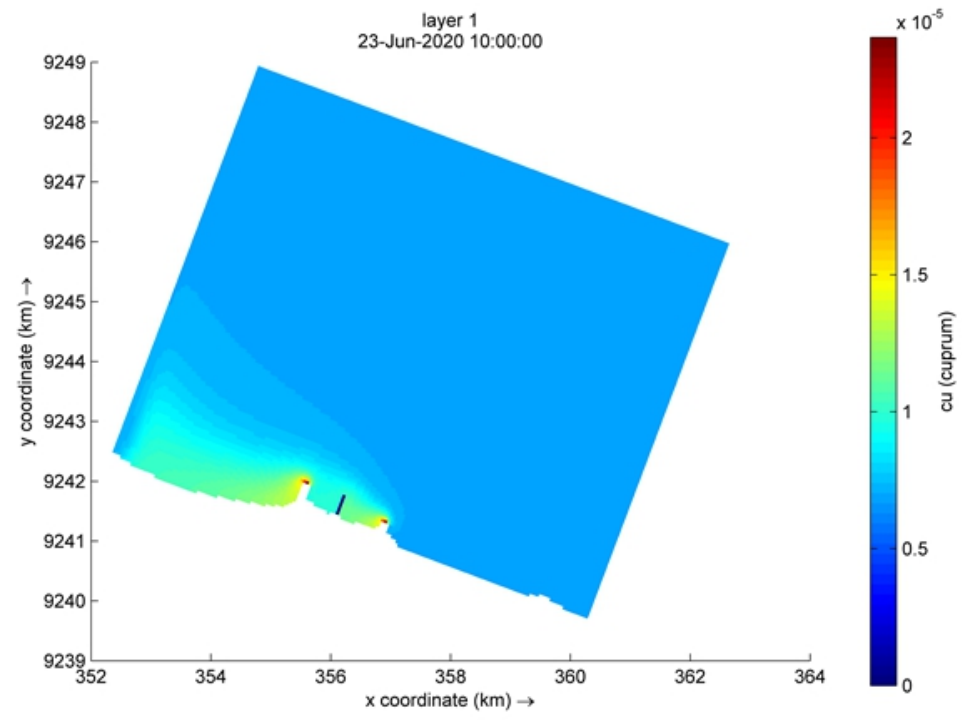

Gambar 13. Persebaran Cu pada tanggal 23 Juni 2020, kondisi pasang menuju surut.

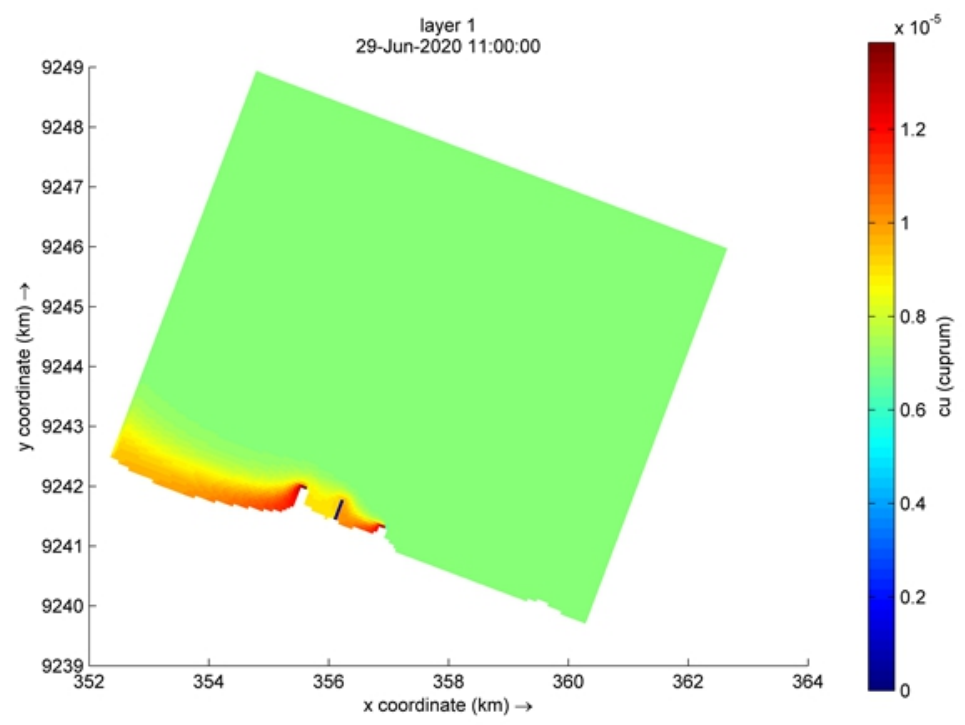

Gambar 14. Persebaran Cu pada tanggal 29 Juni 2020, kondisi pasang menuju surut. 


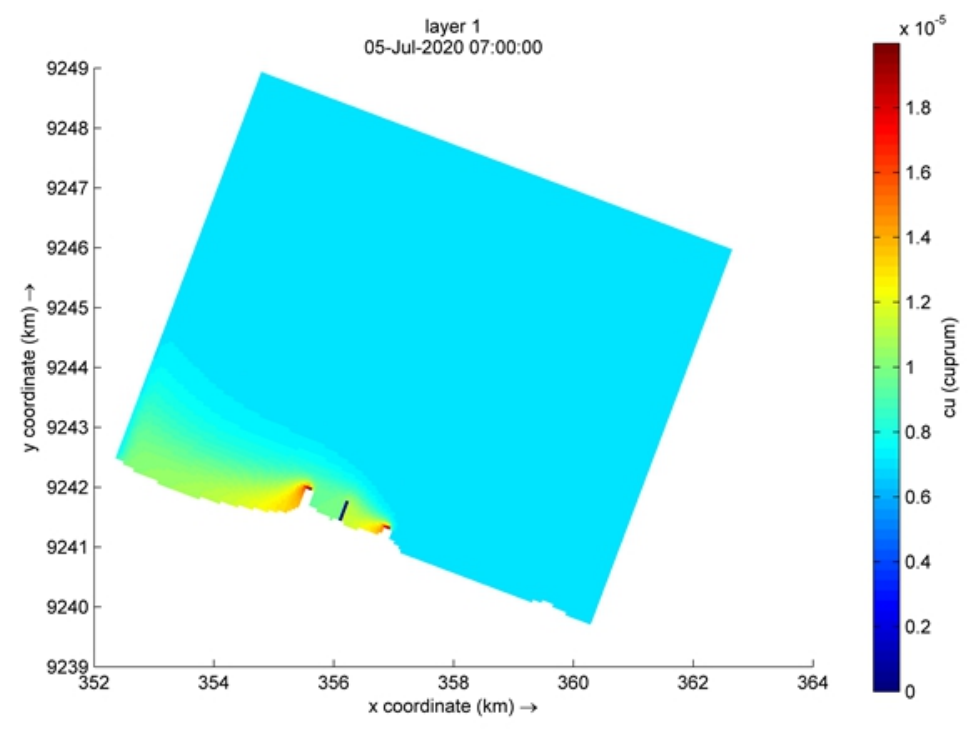

Gambar 15. Persebaran Cu pada tanggal 05 Juli 2020, kondisi pasang menuju surut.

\section{Konsentrasi $\mathbf{C u}$}

Berdasarkan hasil dari pengamatan dan analisa lab konsentrasi $\mathrm{Cu}$ (Cuprum) di perairan Kota Pekalongan memiliki nilai konsentrasi $<0,002 \mathrm{mg} / \mathrm{l}$.

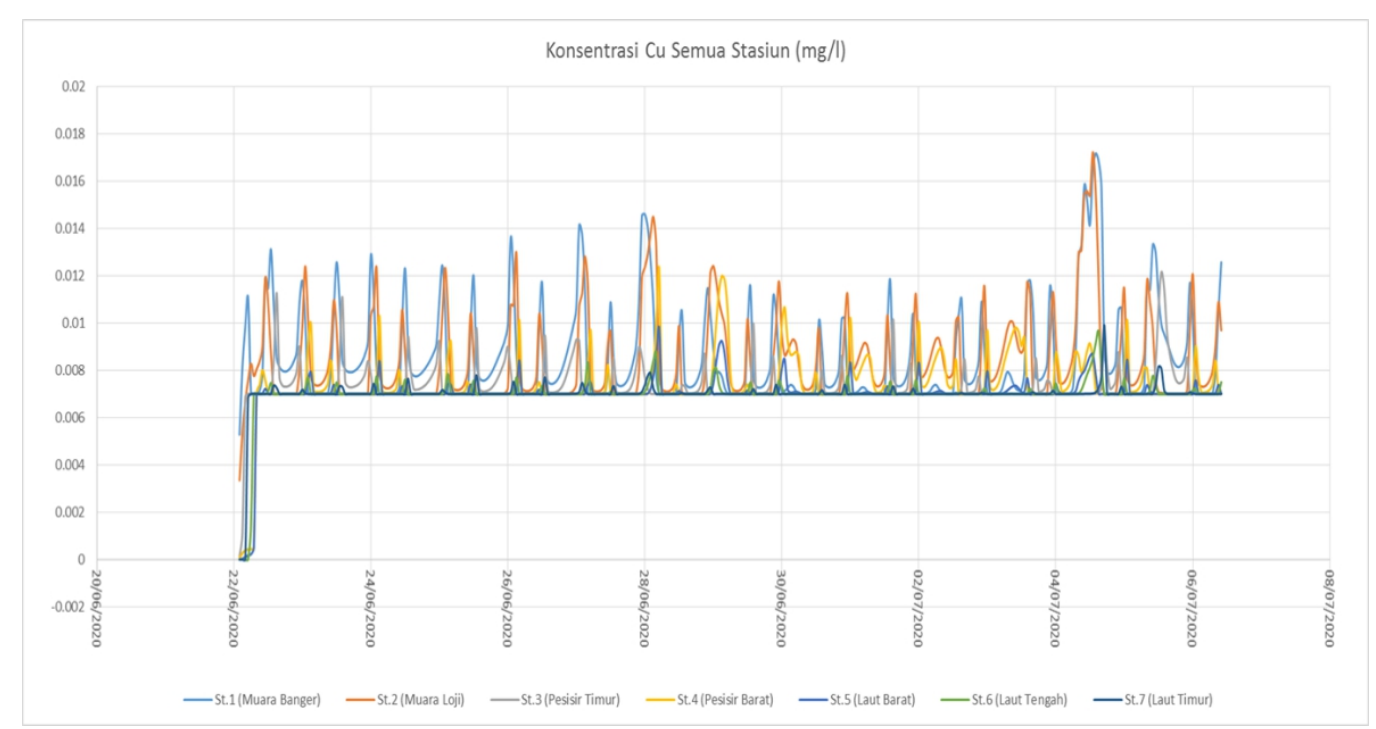

Gambar 16. Grafik Konsentrasi Cu Hasil Pemodelan juni, 2020 


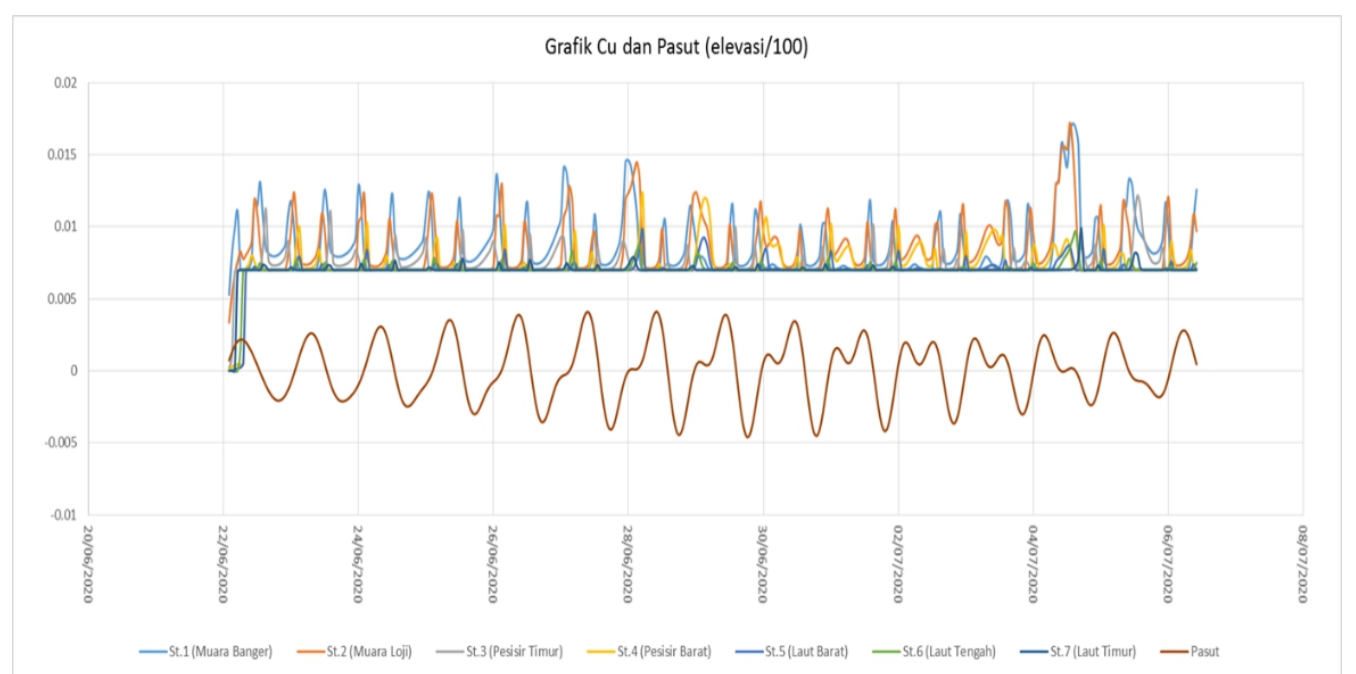

Gambar 17. Grafik Konsentrasi Cu Hasil Pemodelan dan Pasang Surut

Konsentrasi $\mathrm{Cu}$ (Cuprum) pada perairan Kota Pekalongan terbesar pada titik-titik stasiun yang berada didekat pesisir, berturut-turut nilai rata-rata dari konsentrasi terbesar ke terkecil dimulai dari stasiun 1 (muara sungai banger) $0,010973 \mathrm{mg} / 1$, stasiun 2 (muara sungai loji) 0,010052, stasiun 4 (pesisir barat) 0,0077, dan stasiun 3 (pesisir timur) 0,00713 Gambar 16. Sedangkan pada stasiun laut tidak terlalu ada perubahan konsentrasi yang signifikan, hanya terdapat peningkatan konsentrasi di stasiun 5 (laut barat) 0,00724 dan pada kedua stasiun lainnya hanya memiliki konsentrasi yang sesuai dengan kondisi awal laut yaitu 0,007 $\mathrm{mg} / \mathrm{l} \mathrm{Gambar}$ 16. Berdasarkan nilai yang sudah dijelaskan dan pola hasil simulasi persebaran $\mathrm{Cu}$ (Cuprum) menunjukan bahwa arus sejajar pantai (Longshore current) memiliki pengaruh yang cukup besar pada arah persebaran logam berat $\mathrm{Cu}$ (Cuprum). Pada Gambar 13 - Gambar 15 sebaran $\mathrm{Cu}$ (Cuprum) kita mengetahui bahwa arus pasang surut tidak begitu berpengaruh dengan kondisi sebaran logam berat $\mathrm{Cu}$ (Cuprum) di perairan Kota Pekalongan, sesuai dengan penelitian (Damayanti et. al. , 2013) arus dominan yang bekerja di perairan Pekalongan adalah arus nonpasut. Pada daerah muara sungai juga terjadi proses mixing sehingga keberadaan $\mathrm{Cu}$ di kolom air akan segera berikatan dengan sedimen dan unsur-unsur yang ada pada kolom air tersebut.

Pada fase air surut $\mathrm{Cu}$ (Cuprum) condong menyebar luas dari titik lepasan menuju laut (Gambar 13 15). Sedangkan persebaran pada fase air laut pasang cenderung menyebar disekitar titik sumber lepasan. Secara umum, saat menuju pasang arah persebarannya mendekati pantai, sesuai dengan Purnama (2015) bahwa air pasang akan membawa elemen dari laut kedalam muara sungai untuk diendapkan di dalam muara sedangkan pada kondisi menuju surut terendah, arah persebaran dari titik lepasan menyebar luas ke arah lepas pantai. Pola persebaran ini didukung oleh pendapat Ismanto et al. (2019) bahwa pada saat surut, energi yang tercipta karena perubahan elevasi muka air laut lebih rendah apabila dibandingkan dengan pada saat pasang, yaitu ditandai dengan permukaan air yang tenang dan pergerakan massa air dari atau menuju ke laut relatif kecil. Pada grafik konsentrasi $\mathrm{Cu}$ (Cuprum) dan pasang surut gambar 17, kita dapat melihat bahwa tren grafik konsentrasi $\mathrm{Cu}$ akan meningkat disaat tren grafik pasang surut mengalami penurunan/ keadaan surut, disini dinyatakan bahwa disaat keadaan surut aliran arus (debit) sungai akan membawa material dari sungai tersebut (Ismanto et al., 2019) yang merupakan inputan untuk logam berat $\mathrm{Cu}$ (Cuprum) akan meningkat, sehingga kondisi konsentrasi $\mathrm{Cu}$ (Cuprum) di kolom air juga akan ikut meningkat. 
Angin musim sangat mempengaruhi arus musiman di perairan Kota Pekalongan Gambar 9 - 11, sehingga pola arus mengalami perubahan total dua kali setahun sesuai dengan perkembangan musim (Anggraeni et al., 2016). Pada bulan juni-juli arah arus masih dipengaruhi oleh hembusan angin dari tenggara, (musim timur) Indonesia yang memiliki kecepatan angin yang kuat sehingga menimbulkan arus sejajar garis pantai (Anggraeni et al. , 2016). Persebaran $\mathrm{Cu}$ (Cuprum) dominan kearah barat, pola persebaran yang seperti ditunjukan pada Gambar 9 - 11 ini besar dipengaruhi oleh arus yang bergerak pada musim timur sejajar pantai (longshore current) dari arah tenggara menuju barat laut yang didukung juga oleh (Rezki et al ., 2013) mengenai kondisi arus di pesisir Kota Pekalongan didominasi oleh arus sejajar pantai (longshore current), hal ini menjelaskan bahwa material yang ada di dalam kolom air laut akan didistribusikan mendekati sejajar sumbu x (barat ke timur pada musim timur).

Nilai konsentrasi $\mathrm{Cu}$ (Cuprum) tertinggi terdapat pada stasiun 1 (Muara Sungai Banger). Hal ini sedikit berbeda dengan konsep arus sejajar pantai (longshore current) yang mengatakan arus akan membawa material ke arah barat pada musim timur, tetapi konsentrasi $\mathrm{Cu}$ pada stasiun 2 (Muara Loji) memiliki nilai rata-rata konsentrasi yang lebih rendah dibanding stasiun 1 (muara banger). Fenomena ini disebabkan karena adanya bangunan pantai berupa groin yang dibangun tegak lurus dengan garis pantai, dimana groin itu akan menahan material yang ada di dalam kolom air (Pranoto et al., 2016) di sisi sebelah timur groin tersebut (pada musim timur,arus bergerak dari arah tengara ke barat laut) sehingga material $\mathrm{Cu}$ (Cuprum) yang keluar dari sungai banger pun tertahan di muara (sisi timur groin). Proses pengadukan pada daerah pesisir muara sungai karena gelombang dan limpahan debit air sungai (kecepatan arus sungai yang tinggi) dapat menyebabkan terjadinya mixing (sedimen dasar kembali terangkat ke kolom air), besarnya arus sungai dan gelombang yang terjadi pada daerah muara di stasiun 1 (Muara Banger) dan stasiun 2 (Muara Loji) ini diduga ikut menjadi penyebab tingginya kandungan logam berat di stasiun ini, perairan ini mempunyai kedalaman yang dangkal sehingga memungkinkan terjadinya resuspensi logam berat karena pengadukan sedimen dasar.

Kita juga tidak lupa bahwa logam berat $\mathrm{Cu}$ (Cuprum) yang berada pada kolom air mudah berikatan dengan senyawa lain (kurang stabil) dan dapat mudah terendap bersama sedimen tergantung dengan ukuran butir sedimen tersebut, dimana wilayah pesisir perairan Kota Pekalongan didominasi oleh ukuran butir pasir dan pasir lanau (Ikhwan et al., 2015) yang mudah mengikat logam berat $\mathrm{Cu}$ (Cuprum) dan memiliki hubungan positif (semakin kecil ukuran butir akan semakin mudah mengikat logam berat) sesuai dengan pernyataan Maslukah (2013), hal ini juga akan membatasi sebaran menjadi tidak terlalu luas dan jauh ke arah laut karena akan segera terendap bersama sedimen di daerah pesisir.

Stasiun-stasiun pengamatan pada daerah laut, hanya satu stasiun yang mengalami peningkatan nilai konsentrasi dari kondisi normal yaitu stasiun 5 (laut barat). Hal ini menunjukkan bahwa arus sejajar pantai (longshore current) bekerja memindahkan logam berat $\mathrm{Cu}$ (cuprum) ke arah barat dan selanjutnya terbawa oleh arus pasang surut hingga sampai pada titik pengamatan di daerah laut stasiun 5 (laut barat).

Nilai konsentrasi $\mathrm{Cu}$ (Cuprum) dari hasil pemodelan pada stasiun 1 (Muara Banger) dan stasiun 2 (Muara Loji) sudah melebihi nilai ambang batas aman bagi biota laut yang ditetapkan oleh Kementrian Lingkungan Hidup yaitu $0,008 \mathrm{mg} / 1$ dan disaat konsentrasi yang cukup tinggi akan bersifat racun sesuai dengan pendapat serta logam berat $\mathrm{Cu}$ (Cuprum) merupakan salah satu logam berat yang paling beracun bagi organisme laut selain merkuri dan perak (Clark, 2003). Hasil model menunjukkan bahwa dapat diduga perairain pesisir kota Pekalongan terutama sekitar muara loji dan banger sudah tercemar. Hal ini juga dibenarkan oleh Dinas Kementrian Perikanan dan Kelautan kota Pekalongan, mereka menyebutkan bahwa cukup sulit untuk menemui/menangkap ikan di sekitar daerah pesisir (bahkan sudah jarang ada ikan) Kota Pekalongan. Para nelayan setidaknya harus berlayar minimal sejauh 5-7 km kearah laut untuk menangkap 
ikan agar tangkapan maksimal. Dinas Kelautan dan Perikanan juga mengatakan bahwa di daerah pesisir Kota Pekalongan juga sudah sangat jarang ditemui karang dan lamun akibat dari pencemaran sungai yang juga sudah sampai mencemari laut.

\section{KESIMPULAN}

Hasil model menunjukkan bahwa pola perseabran $\mathrm{Cu}$ (Cuprum) di Perairan Kota Pekalongan pada musim timur menyebar mengikuti dengan arah gerak arus yaitu arus non-pasut (longshore current/arus sejajar pantai) yang bergerak dominan ke arah barat pada musim timur dan hasil pemodelan persebaran $\mathrm{Cu}$ (Cuprum) pada perairan Kota Pekalongan hanya mendapati 2 stasiun yang sudah dikategorikan mengalami pencemaran (tingkat pencemaran ringan) yaitu stasiun 1 dengan rata-rata konsentrasi $0,011 \mathrm{mg} / \mathrm{l}$ dan stasiun 2 dengan rata-rata konsentrasi $0,01005 \mathrm{mg} / \mathrm{l}$, melainkan pada 5 stasiun lainnya memiliki nilai rata konsentarasi $\mathrm{Cu}$ berturut-turut dari stasiun $3-7$ yaitu $0,00713 \mathrm{mg} / 1,0,0077 \mathrm{mg} / 1,0,00724 \mathrm{mg} / 1,0,007 \mathrm{mg} / 1$, dan 0,007 yang sudah mendekati nilai ambang batas (NAB) $0,008 \mathrm{mg} / 1$ untuk kehidupan biota laut sesuai dengan Peraturan Menteri Lingkungan Hidup Tahun 2004 tentang "Baku Mutu Air laut".

\section{DAFTAR PUSTAKA}

Anggraeni, S., Satriadi, A., and Saputro, A. A. D., 2016. Karakteristik Kecepatan Dan Arah Dominan Arus Sejajar Pantai (Longshore Current) Di Pantai Larangan Kabupaten Tegal Jawa Tengah. Journal of Oceanography, 5(3): 390-397.

Chai, T., and Draxler, R. R., 2014. Root Mean Square Error (RMSE) or Mean Absolute Error (MAE)? Arguments Against Avoiding RMSE in The Literature. Geosci. Model Dev., 7 (3) : 1247-1250.

Clark, R.B. 2003.Marine Pollution. Oxford University Press. New York.

Damayanti, R., Hariadi, H., and Atmodjo, W., 2013. Pengaruh Arus Terhadap Sebaran Muatan Padatan Tersuspensi Di Pantai Slamaran Pekalongan. Journal of Oceanography, 2(1) : 128-142.

Deltares. 2014. Delft3D-Flow: User Manual. Deltares, Delft

Fajri, P. Y. N., Yuwono, A. S., Yuli, S., 2013. Pemodelan Spasial untuk Penentuan Lokasi Instalasi Pengolahan Air Limbah (IPAL) Batik di Kota Pekalongan, Jawa Tengah. Tesis- Pascasarjana IPB

Fitriyah, A.W., Utomo, Y., dan Kusumaningrum, I.K. 2011. Analisis Kandungan Tembaga (Cu) Dalam Air Dan Sedumen Di Sungai Surabaya. Kimia, FMIPA, Universitas Negeri Malang,

Ikhwan, R., Saputro, S., and Hariadi, H., 2015. Studi Sebaran Sedimen Dasar Di Sekitar Muara Sungai Pekalongan, Kota Pekalongan. Journal of Oceanography, 4(3) : 617 - 624.

Ismanto, A., D.H., Ismunarti. D.N., Sugianto. S., Maesyarah. P., Subardjo. Suryoputro, A. A. D. and H., Siagian. 2019. The Potential of Ocean Currentas Electrical Power Sources Alternatives in Karimunjawa Islands Indonesia. ASTES, 4(6): 126-133

Maslukah, L., 2013. Hubungan antara Konsentrasi Logam Berat Pb, Cd, Cu, Zn dengan Bahan Organik dan Ukuran Butir dalam Sedimen di Estuari Banjir Kanal Barat, Semarang. Buletin Oseanografi Marina, $2(3): 55-62$.

Mratihatani, A.S. 2013. Menuju Pengelolaan Sungai Bersih Di Kawasan industri Batik Yang Padat Limbah Cair (Studi Empiris : Watershed Sungai Pekalongan di Kota Pekalongan) . FEB UNDIP Semarang.

Pemerintah Kota Pekalongan Jawa Tengah. 2019. https://Pekalongankota.go.id/

Pemerintah Propinsi Jawa Tengah. 2019. https://jatengprov.go.id/.

Pranoto, H., Atmodjo, W. and Sugianto, D. N., 2016. Studi Sedimentasi Pada Bangunan Groin di Perairan Timbulsloko, Kabupaten Demak. Journal of Oceanography, 5 (1) : 86 - 95.

Prasetya, A., Yudianto, D. dan Guan, Y., 2017. Pemodelan Numerik 1-D Adveksi-Dispersi Untuk Memprediksi Konstrentasi Polutan Dalam Badan Sungai . Jurnal Teknik Sipil. 14(3) : 188 - 194.

Purnama, A.E., Hariadi, H., dan Saputro, S., 2015. Pengaruh Arus, Pasang Surut Dan Debit Sungai Terhadap Distribusi Sedimen Tersuspensi Di Perairan Muara Sungai Ciberes, Cirebon. Jurnal Oseanografi., $4(1): 74-84$. 
Rezki, C.T., Subardjo, P., Wulandari, S.Y. 2013. Studi Sebaran Logam Berat Pb (Timbal) Pada Sedimen Dasar Perairan Pantau Slamaran Kota Pekalongan. Jurnal Oseanografi, 2(1)

Sudjana, M. M. 1992. Metode Statistika. Tarsito. Bandung

Sugiyono. 2009. Metode Penelitian Kuantitatif Kualitatif. Alfabeta, Bandung. 